\title{
EVALUATION OF LOW ASSAY PU-238 OXIDE FOR USE IN \\ FABRICATION OF PLASMA-FIRED MICROSPHERES
}

May 15, 1968

R. D. Madding, Jr. R. E. Valle

RECEIVED

JUL 011996

OSTI

\section{MONGANTO REGEARCH CORPORATION}
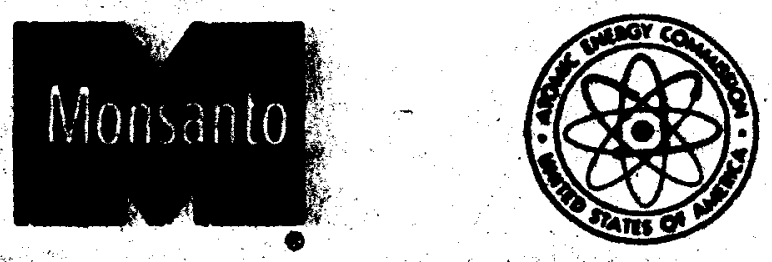

\section{O U N D \\ MIAMISBURG, OHIO \\ LABORATORY OPERATED FOR \\ UNITED STATES ATOMIC ENERGY COMMISSION

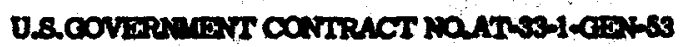

DSTRIBUTION OF THIS DOCUMENT IS UNLIMITES

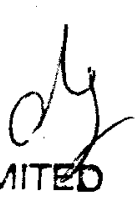




\section{DISCLAIMER}

This report was prepared as an account of work sponsored by an agency of the United States Government. Neither the United States Government nor any agency Thereof, nor any of their employees, makes any warranty, express or implied, or assumes any legal liability or responsibility for the accuracy, completeness, or usefulness of any information, apparatus, product, or process disclosed, or represents that its use would not infringe privately owned rights. Reference herein to any specific commercial product, process, or service by trade name, trademark, manufacturer, or otherwise does not necessarily constitute or imply its endorsement, recommendation, or favoring by the United States Government or any agency thereof. The views and opinions of authors expressed herein do not necessarily state or reflect those of the United States Government or any agency thereof. 


\section{DISCLAIMER}

Portions of this document may be illegible in electronic image products. Images are produced from the best available original document. 


\section{DISCLAMIXR}

Portions of this document may be illegible in electronic image products. Images are produced from the best avallable original document. 


\title{
EVALUATION OF LOW ASSAY Pu-238 OXIDE FOR USE IN \\ FABRICATION OF PLASMA-FIRED MICROSPHERES
}

May 15,1968 Compiled by: R. D. Madding, Jr.
Approved by: R. E. Vallèe

\author{
Monsanto Research Corporation \\ Mound Laboratory \\ Miamisburg, Ohio
}

\section{DISCLAIMER}

This report was prepared as an account of work sponsored by an agency of the United States Government. Neither the United States Government nor any agency thereof, nor any of their employees, makes any warranty, express or implied, or assumes any legal liability or responsibility for the accuracy, completeness, or usefulness of any information, apparatus, product, or process disclosed, or represents that its use would not infringe privately owned rights. Reference herein to any specific commercial product, process, or service by trade name, trademark, manufacturer, or otherwise does not necessarily constitute or imply its endorsement, recommendation, or favoring by the United States Government or any agency thereof. The views and opinions of authors expressed herein do not necessarily state or reflect those of the United States Government or any agency thereof. 


\section{ACKNOWLEDGEMENT}

The efforts of the numerous people in the Nuclear Operations Department who prepared and analyzed the microspheres are hereby acknowledged. 


\section{Introduction}

The desirability of evaluating low assay plutonium-238 ( $23 \%$ Pu-238) oxide was discussed with AEC personnel during a meeting at Germantown on July 6, 1967. In September, 1967 a sample of this material was furnished to Mound for evaluation. This evaluation was to be completed on a schedule which would not interfere with production of material for the SNAP programs, and was to include characterization of the oxide feed, and preparation and subsequent characterization of plasma-fired microspheres according to SNAP-27 procedures. Authorization to perform this work was received from DAO on September 1, 1967.

\section{Fabrication of Microspheres}

The Pu-238 oxide microspheres were fabricated from oxide feed received from the Savannah River Plant (SRP). The feed material was assayed by Mound Laboratory prior to microsphere preparation. Ahout 30 grams of this feed material were used in preparing feed for the torch by the hydroxide precipitation method. This work, including high temperature sintering, was performed on a laboratory scale in the Research Building. The resultant torch leed was plasma-fired in the production torch in SM, sized by screening, and segregated to remove nonspherical particles.

These microspheres were then subjected to characterization according to SNAP-27 procedures, with the exception of the fines determination. Fines data on the small quantity of low assay microspheres obtained could not be considered comparable to that obtained on a production batch. Additional data collected on the oxide feed and the microspheres is also included in this report. 


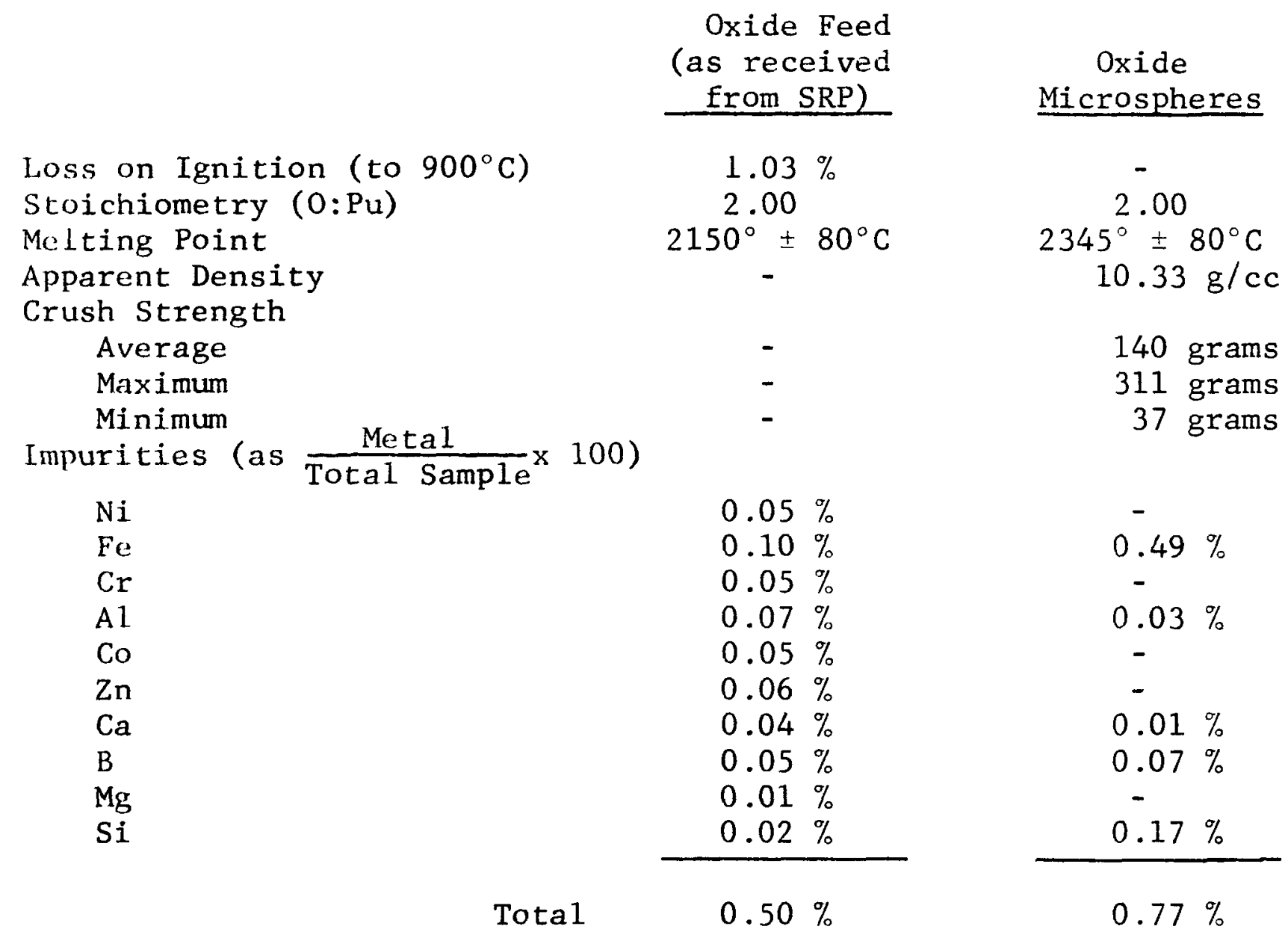

Isotopic and Actinide Analysis

Result reported as $\left(\frac{\text { Isotope }}{\text { Total Pu Metal }} \times 100\right)$

$\begin{array}{lcrr}\text { Element } & \text { Error }^{1} & \begin{array}{r}\text { Oxide Feed } \\ \text { (as received } \\ \text { from SRP) }\end{array} & \begin{array}{r}\text { Oxide } \\ \text { Microspheres }\end{array} \\ \text { Th-232 } & - & <0.010 \text { wt \% } & <0.010 \text { wt \% } \\ U-234 & \pm 10 \% & 0.162 \text { wt \% } & 0.162 \text { wt \% } \\ i-235 & - & <0.010 \text { wt \% } & <0.010 \text { wt \% }\end{array}$




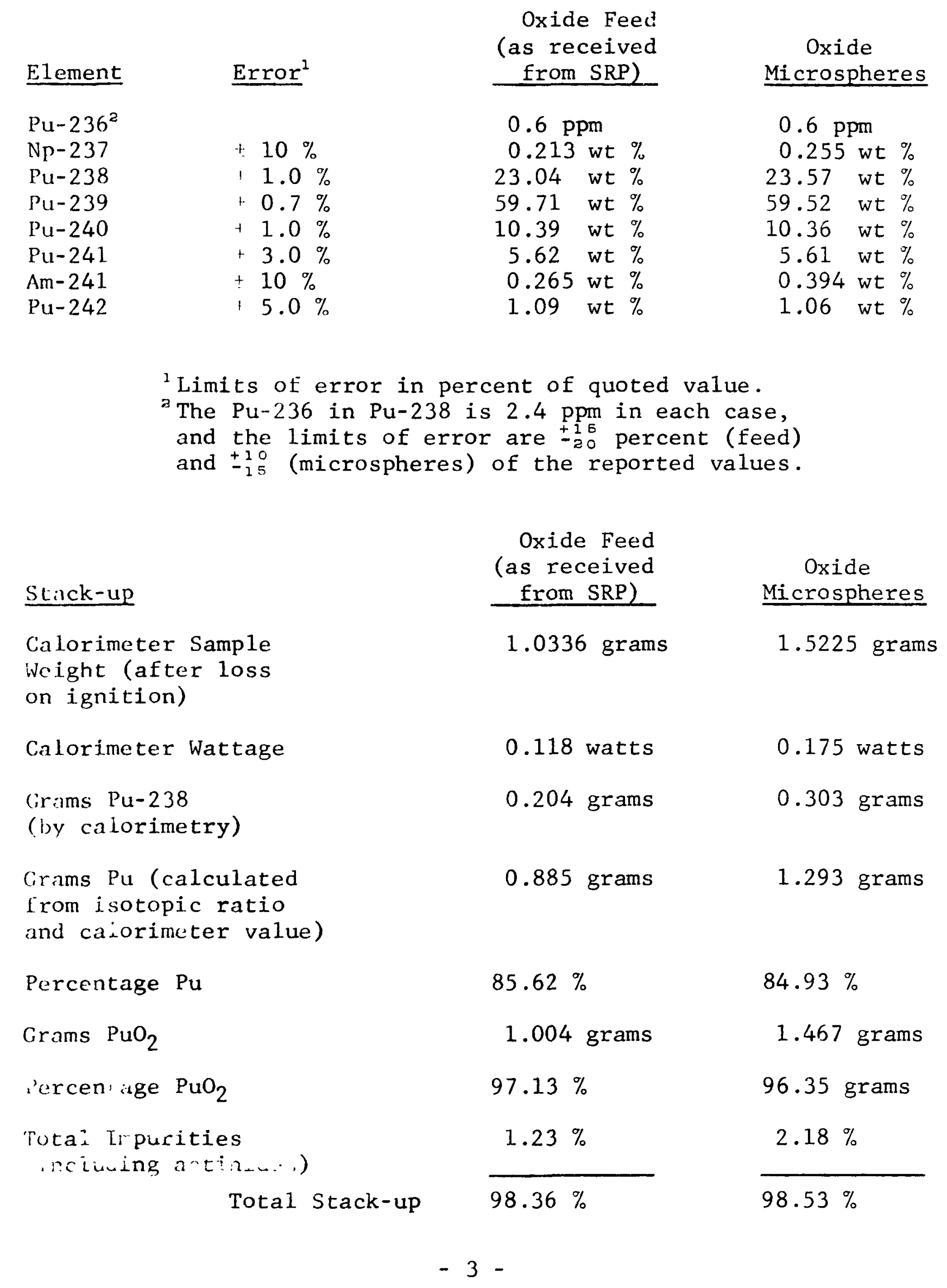


It will be noted from the above data that the ave aye crush strength of 140 grams does not meet the SNAP-27 specification. Since it is known that the crush strength is related to the size of the particles, a particle size measurement was made on a sample of 1667 particles. The average particle size was Found to be 90 microns. From data collected on production grade $\mathrm{Pu}^{238} \mathrm{O}_{2}$ microspheres, the crush strength of this size particle is expected to be $\sim 120$ grams. It is therefore concluded that the low assay material is equivalent to the production grade material with respect to crush strength.

\section{Oxide Feed Gamma Spectra}

The gamma ray spectra obtained for the low and high energy ranges are shown in Figures 1 and 2 respectively. These spectra were obtained with a standard $\mathrm{NaI}(\mathrm{T} 1)$ detector 3 " in diameter by 3" long positioned at approximately one meter from the source.

There is a greater than usual thallium-208 contamination to the $\mathrm{Pu}-238$ spectrum, as would be expected, since the low assay material has a higher $\mathrm{Pu}-240$ and $\mathrm{Pu}-236$ content than is typically found in the normal $80 \%$ enriched material. Also, the $203 \mathrm{keV}$ gamma ray is more intense and broader than normal. This is due to the added contribution from the $203 \mathrm{keV} \mathrm{Pu}-239$ gamma ray and the $208 \mathrm{keV}$ gamma ray from U-237.

\section{Oxide Microsphere Gamma Spectra}

Figures 3 and 4 show the gamma ray spectra obtained on a sample of . ze microspheres. Figure 3 covers the low energy range and Figure 4 the high energy range. Both spectra were obtained with a standard NaI(T1) detector $3^{\prime \prime}$ in diameter by $3^{\prime \prime}$ high positioned at approximatel" one meter from the source.

In comparison with spectra obtained on the normal $80 \%$ enriched macerial, the contribution from $\mathrm{Pu}-238$ to the gamma ray spectra has decreased while the contributions from $\mathrm{Pu}-239$ have greatly increased as , idenced by the prominence of the $52 \mathrm{keV}$ gamma ray. Also, the 20. keV gamma ray is more intense and broader than normal. This is due to the added contribution from the $203 \mathrm{keV} \mathrm{Pu}-239$ gamma rny and the $208 \mathrm{keV}$ gamma ray from U-237. 
Oxide Feed Neutron Emission and Spectrum

On March 6, 1968, the total neutron emission rate of this sample (containing $20.3 \mathrm{~g}$ of $\mathrm{Pu}-238$ ) was determined to be $3.89 \times 10^{5} \mathrm{n} / \mathrm{s}$ with an absolute uncertainty of $\pm 7 \%$. This is a specific yield of $1.92 \times 10^{4} \mathrm{n} / \mathrm{s}-\mathrm{g} \mathrm{Pu}-238$.

Figure 5 shows the measured neutron spectra for the same $20.3 \mathrm{~g}$ Pu-238 sample. This spectra is quite similar to other $238 \mathrm{PuO}_{2}$ spectra, clearly showing neutrons from the $180(\alpha, n)$ reaction and from spontaneous fission of $\mathrm{Pu}-238$. The portion of the measured spectrum which may be different from some other oxide samples is the region from $1-1.5 \mathrm{MeV}$. Some oxide spectra have shown about the same neutron intensity in this region while others have shown slightly less. At this point in time it is not known whether these differences are real or due to experimental uncertainty. It is known that there are differences of $5-10 \%$ in the specific yields of different oxide sources and perhaps these differences are showing up in the spectra in the $1-1.5 \mathrm{MeV}$ region.

\section{Oxide Microsphere Neutron Emission}

Neutron emission measurements were made of a sample (containing $0.70 \mathrm{~g}$ of $\mathrm{Pu}-238$ ) of microspheres, with the total emission rate of this sample found to be $1.34 \times 10^{4} \mathrm{n} / \mathrm{s}$ on February 23, 1968, with an absolute uncertainty of about $\pm 7 \%$. The specific yield is then $1.90 \times 10^{4} \mathrm{n} / \mathrm{s}-\mathrm{g} \mathrm{Pu}-238$.

Photo

Photo 1 shows a sample of the assay microspheres at about $100 \mathrm{X}$ magnification. The size and shape of these particles were investigated and found to meet SNAP-27 specifications.

\section{Conclusions}

The low assay ( 23\%) plutonium-238 oxide behaved no differently than the normal $(\sim 80 \%)$ plutonium-238 oxide throughout the feed preparation and microsphere fabrication steps of the production 
- process. The only significant characteristic which is different from the normal material is the higher Pu-236 in Pu-238 content of the low assay material.

Based on this evaluation, it is concluded that the low assay material can be processed to acceptable product without changing the production processes. 


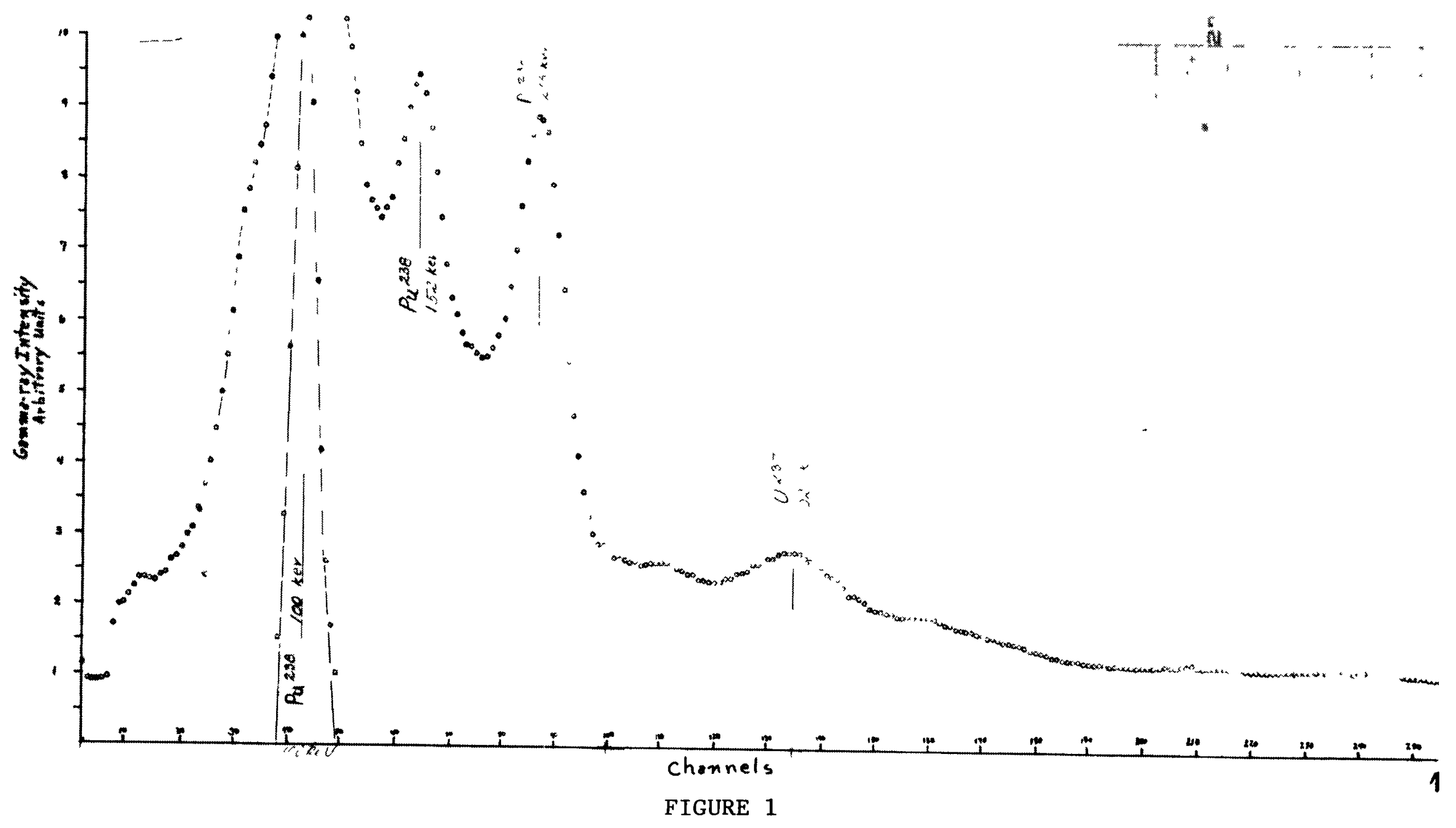

Low Assay Oxide Feed Gamma Spectra

Range: 50 to $600 \mathrm{keV}$ 


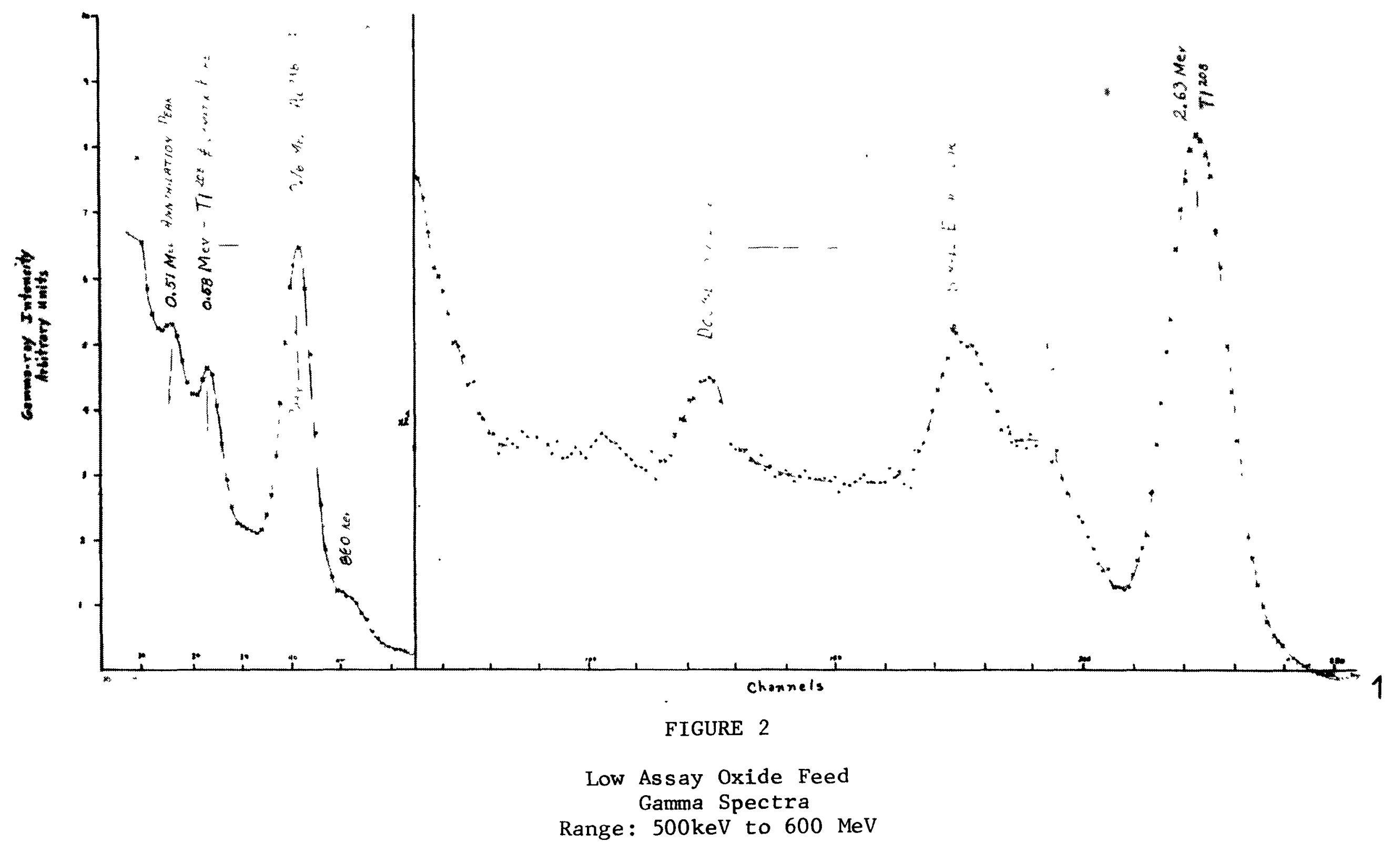




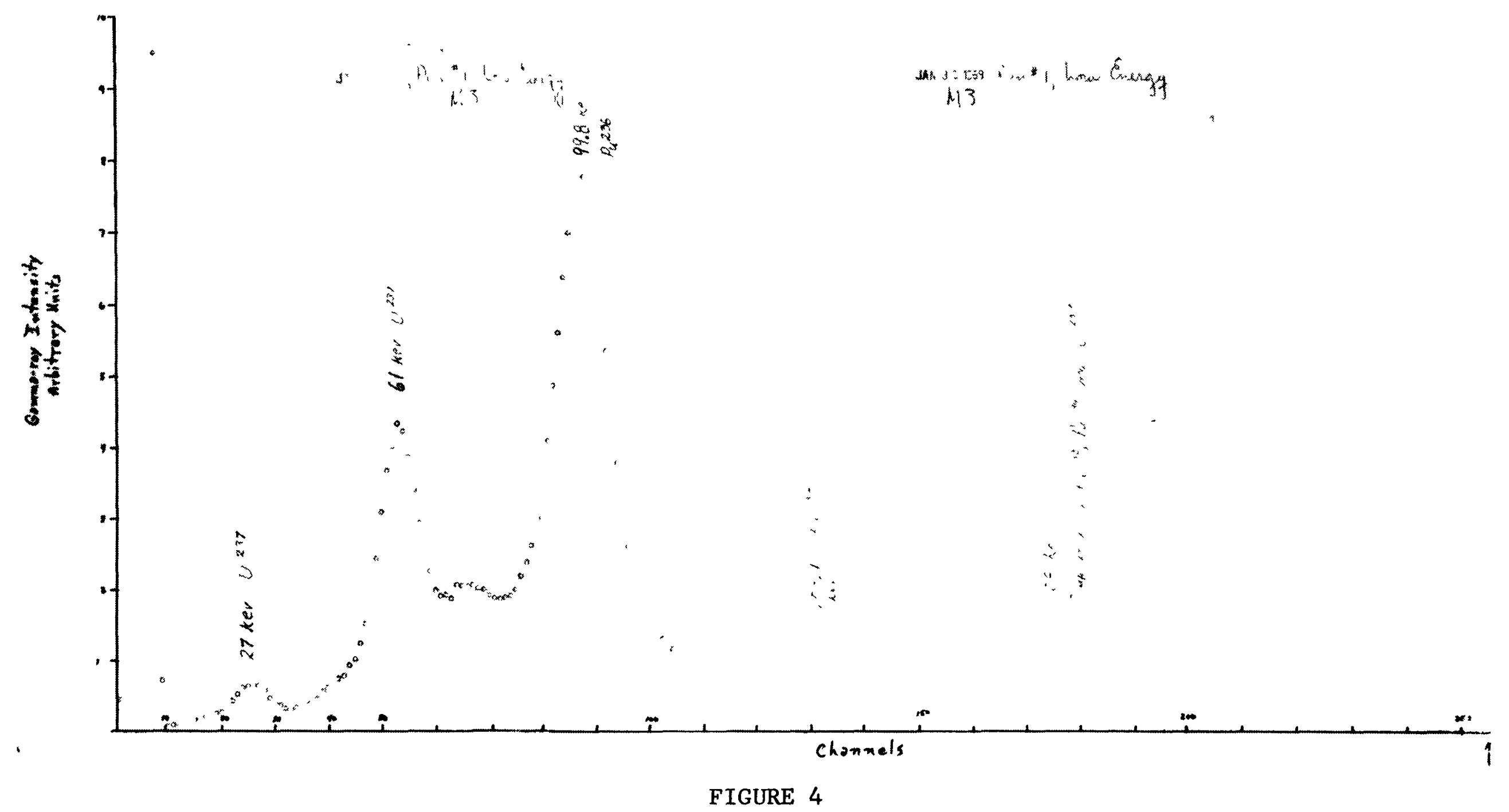

Low Assay Oxide Microspheres

Gamma Spectra

Range: $500 \mathrm{keV}$ to $3.0 \mathrm{MeV}$ 


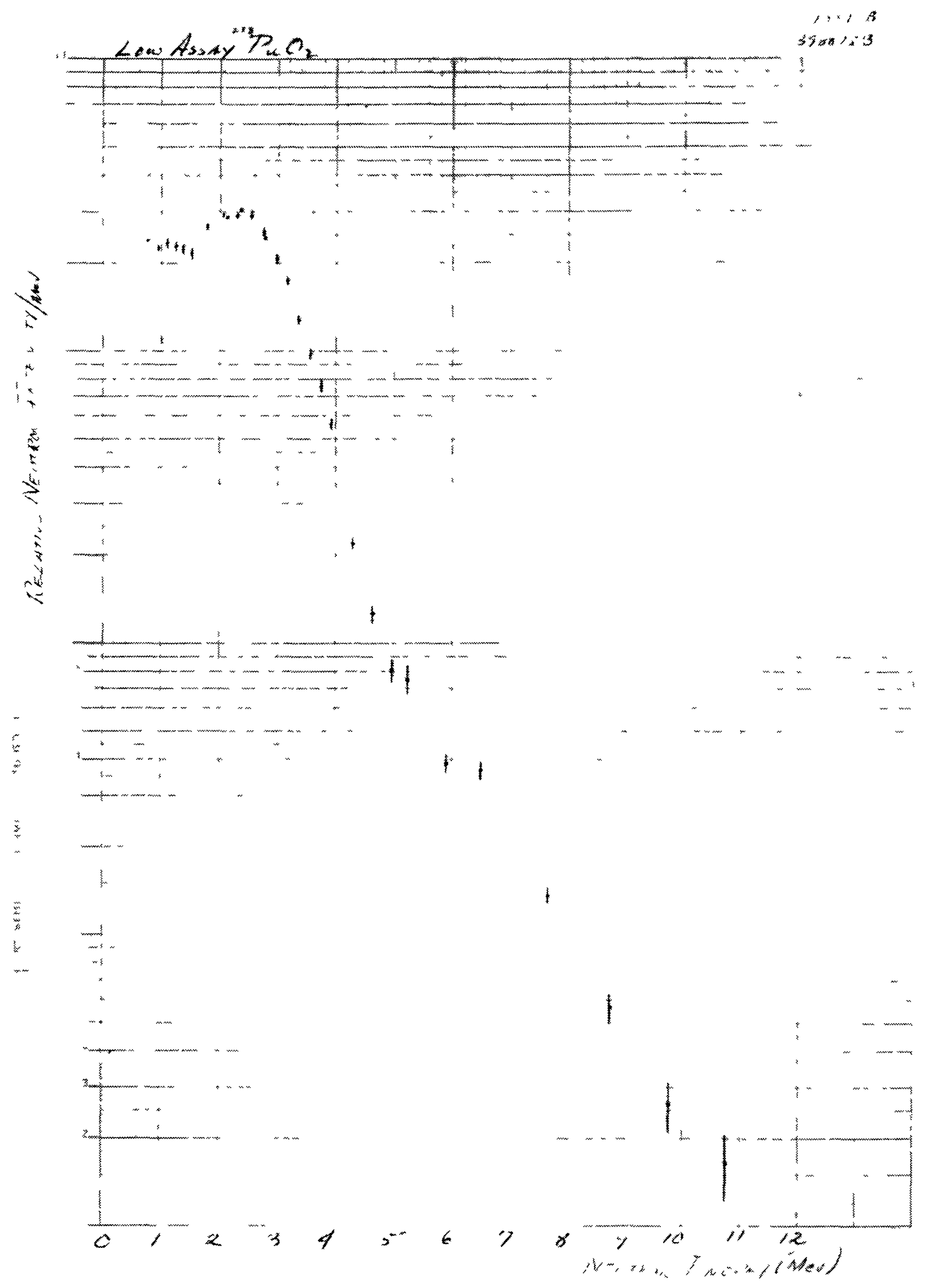

FIGURE 5

Low Assay Oxide Feed Neutron Energy Spectra 


\title{
PHOTO 1
}

\author{
A Sample of the Low Assay Microspheres \\ at about 100X Magnification
}




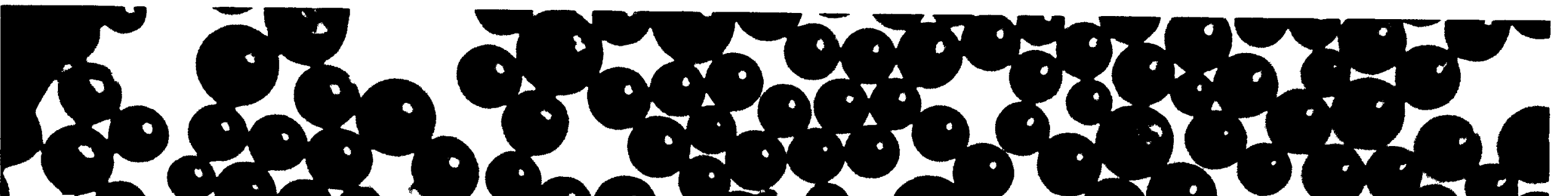

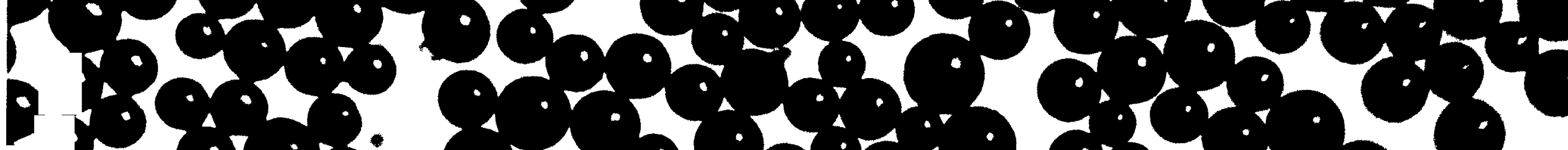

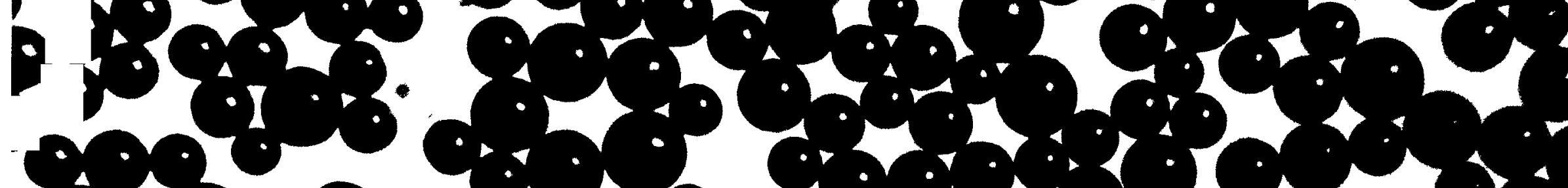
38 ise \% - 